\title{
Molluscicidal Activity of Natural Products. The Effect of Solanum Glycosidic Alkaloids on Lymnaea cubensis Snails ${ }^{1,2}$
}

\author{
Arnaldo Alzérreca, Bolívar Arboleda, and Georgina Hart ${ }^{3}$
}

\begin{abstract}
The progressive increase of bovine fascioliasis in Puerto Rico demands the control of the population of the intermediate snail host. This report deals with preliminary results of the effect of extracts of Solanum mammosum fruits on Lymnaea cubensis snails. The methanolic crude extract shows $95 \%$ molluscicidal activity at $25 \mathrm{p} / \mathrm{m}$. One component of the active extract was identified as solasod-5-en-3 $\beta$-ol (solasodine).
\end{abstract}

\section{INTRODUCTION}

Molluscicidal research has made considerable advances, especially in the control of bilharziasis. For Fasciola hepatica, however, there is still need for molluscicides which can be obtained from local plant material. A progressive increase in the percentage of cattle infected with this parasite in Puerto Rico has been reported in recent slaughterhouse studies (4). A 1978 survey of dairy cattle on farms throughout the island revealed that the increase in bovine fascioliasis is higher than previously reported (5). In connection with our study on biologically active compounds from plants we examined the fruits of the plant Solanum mammosum (berenjena de cucaracha), which was previously observed to have molluscicidal properties $(1,6)$. The present paper reports the evaluation of the toxicity of water and methanol extracts of Solanum mammosum fruits on the local snail vector Lymnaea cubensis and the chemical analysis of the strong molluscicidal methanolic extract.

\section{MATERIALS AND METHODS}

Solanum mammosum fruits were collected in Dorado and Caguas, Puerto Rico, during March, April, and July. Lymnaea cubensis snails used in this study were cultured under standard laboratory conditions in

Manuscript submitted to Editorial Board September 18, 1979.

${ }^{2}$ Presented in part at the 3rd. Senior Technical Meeting of the American Chemical Society, Puerto Rico Section, Mayagüez, December, 1978. Research support from MBSNIH Grant No. 1 SO6 RR 08159.

${ }^{3}$ Associate Professor of Organic Chemistry, Department of Natural Sciences, Inter American University of Puerto Rico, P.O. Box 1293, Hato Rey, P.R. 00919, and MBS-NIH undergraduate research participants.

The authors express appreciation to P. Bendezú and F. Medina for helpful suggestions; also to thank R. Woodbury, University of Puerto Rico; and E. E. Terrel, Beltsville Agricultural Research Center, Ma., for the identification of the Solanum fruits; and Dr. J. Szobota, University of Puerto Rico for recording the mass spectrum of solasodine. 
plastic boxes provided with mud from the original snail habitat under continuous flow of dechlorinated and charcoal-sand filtered tap water.

\section{PREPARATION OF CRUDE EXTRACTS}

The ripe fruits were dried at $50^{\circ} \mathrm{C}$ and ground in a blender; $375 \mathrm{~g}$ of this material was extracted wih methanol:water (9:1). After filtration through glass wool and filter paper, vacuum evaporation of the solvent gave $23.3 \mathrm{~g}(6.2 \%)$ of a brown residue. For the water extract, $20 \mathrm{~g}$ of the dried and ground ripe fruits were stirred at room temperature for 24 hours with $500 \mathrm{ml}$ of distilled water. After filtration, the residue was dried and weighed, and the solution was made up to a desired concentration for analysis.

\section{SEPARATION OF ACTIVE FRACTIONS}

Thin layer chromatography of the crude methanolic extract on silica gel plates with chloroform:methanol $(5: 1)$ revealed the presence of nine spots. Addition of ammonia to a hot solution of the methanolic crude extract in $3 \%$ acetic acid produced a light brown precipitate which was filtered, washed with cold water and dried with air. Column chromatography of this precipitate on silica gel with chloroform:methanol $(3: 1)$ afforded a solid that showed only two spots on silica gel plates, chloroform: methanol $(5: 1)$. This mixture $(300 \mathrm{mg})$ was heated with $5 \%$ hydrochloric acid for 3 hours. The reaction mixture was basified with ammonia and extracted with chloroform. The organic phase was washed with water, dried over $\mathrm{MgSO}_{4}$, filtered and the solvent was evaporated under reduced pressure. Column chromatography of the resulting residue on $\mathrm{Al}_{2} \mathrm{O}_{3}$ with ether and recrystallisation from methanol yielded $98.1 \mathrm{mg}$ $(70 \%)$ of crystalline plates, m.p. $197-199^{\circ} \mathrm{C}$. This product was identified by comparison of the IR and MS spectra as the steroidal solanum alkaloid solasod-5-en-3 $\beta$-ol (solasodine).

\section{TOXICITY TESTS}

Bioassays were carried out with 30-day-old Lymnaea cubensis snails of uniform sizes (average length: $4 \mathrm{~mm}$ ). Each test was made with two replicates of 10 snails placed in petri dishes with dechlorinated and filtered water solutions of known extract concentration. The test included a 24-hour exposure and a 24-hour recovery period. After this time, the snails were observed under the microscope. Control runs were carried out with dechlorinated and filtered tap water.

\section{RESULTS AND DISCUSSIONS}

The toxicity tests showed that the water, and especially the methanol extract of Solanum mammosum fruits, had molluscicidal properties. The water extract killed 25\% of the population of the snails Lymnaea cubensis 
at the concentration of $100 \mathrm{p} / \mathrm{m}$ (table 1 ). The molluscicidal activity is strongly increased by extraction with methanol. Water solution of the methanolic crude extract showed $95 \%$ mortality at $25 \mathrm{p} / \mathrm{m}$. Therefore, special attention was given to the chemical composition of the methanol extract. As described in the separation of fractions, column chromatography of the crude methanol extract afforded a fraction containing a mixture of two components. Water solution of this mixture produced $100 \%$ mortality at $10 \mathrm{p} / \mathrm{m}$ (table 1). From these results, it is evident that in this mixture two strong molluscicidal products from Solanum mammosum were obtained. Isolation and further activity studies of each of these products is now in progress. Nevertheless, hydrolysis of the mixture afforded only one alkaloid which was identified as solasodine. These results suggest that the strong molluscicidal products are the steroid glycoalkaloids solasonine and solamargine. Both glycosidic alkaloids contain solasodine and differ only in the sugar moiety $(2,3,8)$. Earlier studies

TABLE 1.-Molluscicidal effect of active extracts obtained from Solanum mammosum fruits on Lymnaea cubensis snails expressed as mortality percentage

\begin{tabular}{lrrrrrrr}
\hline \multicolumn{1}{c}{ Active principle } & \multicolumn{7}{c}{ Concentration $(\mathrm{p} / \mathrm{m})$} \\
\cline { 2 - 8 } & 100 & 75 & 50 & 25 & 10 & 5 & 1 \\
\hline Water extract & 25 & 17 & 10 & 5 & 0 & 0 & 0 \\
Methanol extract & 100 & 100 & 100 & 95 & 35 & 10 & 0 \\
$\begin{array}{l}\text { Mixture of glycosidic alka- } \\
\quad \text { loids }\end{array}$ & 100 & 100 & 100 & 100 & 100 & 30 & 10 \\
\hline
\end{tabular}

also report the presence of solasonine and solamargine in Solanum mammosum fruits $(7,9)$. Solasodine itself showed no toxicity in water. This can be explained on the basis of the low water solubility of the alkaloid. Extraction with other less polar solvents has yielded residues with no significant toxicity.

\section{RESUMEN}

El incremento en la incidencia de la Fasciola hepatica en el ganado de Puerto Rico hace necesario controlar el caracol transmisor del parásito. Este estudio determinó el efecto de los frutos de la planta Solanum mammosum (berenjena de cucaracha) sobre caracoles Lymnaea cubensis. El extracto metanólico bruto demostró una actividad moluscicida de $95 \%$ a la concentración de $25 \%$ en solución acuosa. Una fracción cromatográfica del crudo metanólico aumentó su potencia moluscicida a $100 \%$ en una concentración de 10 ppm. Se identificó un producto del extracto metanólico activo como solasod-5-en-3 $\beta$-ol (solasodina).

\section{LITERATURE CITED}

1. Bendezú, P., personal communication, 1978.

2. Briggs, L. H. and Cambie, R. C., 1958. The examination of the alkaloids from seven 
Solanum species, J. Chem. Soc. (Lond), 1422.

3. - - , and Hoare, J. L., 1963. The sugar moiety of solasonine, J. Chem. Soc. (Lond), 2848

4. Frame, A. D., Bendezú, P., Mercado, H., Otiniano, H. Frame, S. J., and Flores, W., 1979. Increases of bovine fascioliasis in Puerto Rico as determined by slaughterhouse surveys, J. Agri. Univ. P. R., 63 (1):27-30.

5. - - - Rivera-Ortiz, C. I., Valentín, R., and Diaz-Rivera, J., 1979. The prevalence of Fasciola hepatica in cattle of the dairy farms in Puerto Rico, submitted for publication in J. Parasitol.

6. Medina, F. R. and Woodbury, R., 1979. Terrestrial plants molluscicidial to I ymnaeid hosts of Fasciola hepatica in Puerto Rico, J. Agri. Univ. P. R., 63 (3):366-76.

7. Pérez-Medina, L. A., Tracevedo, E., and Devia, J. E., 1964. Glycoalkaloids in Colombian Solanacea, Planta Med. 12:478-87.

8. Schreiber, K., 1968. Steroid Alkaloids: the Solanum group. In Manske, R. H. F., The Alkaloids, Vol. 10. Academic Press, New York.

9 Telek, L., Delpín, H. and Cabanillas, E., 1977. Solanum mammosum as a source of solasodine in the lowland tropics, Econ. Bot., 31:120-8. 